THE additions to the Zoological Society's Gardens during the past week include a Pudu Deer (Pudu humilis $q$ ) from Chili, presented by Mr. G. E. Pugh Cook; two - Squirrels (Sciurus -) from Demerara, presented by Mr. R. Forrester Daly; a Blue and Yellow Macaw (Ara ararauna) from South America, presented by Mrs. Alfred Palmer ; a Pallas's Sand Grouse (Syrrhaptes paradoxus) from Berwick-on-Tweed, presented by Mr. H. Hewart Crane; two Australian Waxbills (Estrelda temporalis); seven Spotted-sided Finches (Amadina lathami) from Australia, presented by Mr. David S. Hodge; a Nose-crested Iguana (Iguana rhinolopha) from St. Lucia, West Indies, presented by Dr. T. Dennehy ; a Tent Tortoise (Testudo tentoria), a Fisk's Tortoise (Testudo fiski) from Cradock, Cape Colony, a Dwarf Chameleon (Chamaleon pumilus), a Purplish Gecko (Phyllodactylus porphyreus), a Hoary Snake (Coronella cana), three Narrow-headed Toads (Bufo angusticeps), five Gray's Frogs (Rana grayi) from South Africa, presented by the Rev. G. H. R. Fisk; two Tigers (Felis tigris) from India, two Puff Adders (Vipera arietans) from South A frica, deposited; a Long-billed Butcher Crow (Barita destructor) from New Holland, received in exchange; two North African Jackals (Canis anthus), born in the Gardens.

\section{ASTRONOMICAL PHENOMENA FOR THE WEEK 1888 JUNE 10-16.}

(FOR the reckoning of time the civil day, commencing at Greenwich mean midnight, counting the hours on to 24 is here employed.)

At Greenwich on June 10

Sun rises, 3 h. $46 \mathrm{~m}$. ; souths, Irh. $59 \mathrm{~m}$. $15.5 \mathrm{~s}$.; sets, $20 \mathrm{~h} .13 \mathrm{~m}$. right asc. on meridian, 5h. 16.3m.; decl. $23^{\circ} 4^{\prime} \mathrm{N}$ Sidereal Time at Sunset, $13 \mathrm{~h}$. $31 \mathrm{~mm}$.

Moon (New on June 9, r7h.) rises, 4h. $35 \mathrm{~m}$. ; souths, I $2 \mathrm{~h}$. $40 \mathrm{~m}$. ; sets, 2oh. 49m. : right asc. on meridian, 5h. $57^{\circ} 3 \mathrm{~m}$.; decl. $20^{\circ} 45^{\prime} \mathrm{N}$.

Planet. Rises. Souths. Sets. Right asc. and declination

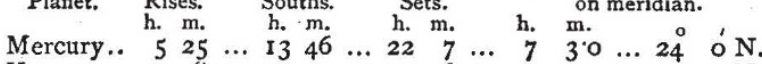
$\begin{array}{lllllllllllllllllll}\text { Venus..... } & 3 & 18 & \ldots & 11 & 22 & \ldots & 19 & 26 & \ldots & 4 & 39.5 & \ldots & 21 & 45 & \mathrm{~N}\end{array}$ $\begin{array}{lllllllllllllllllll}\text { Mars ...... } & \text { I4 } & 0 & \ldots & 19 & 34 & \ldots & \text { I } & 8^{*} & \text {.. } & \text { 12 } & 5_{2}^{2} \cdot 2 & \ldots & 5 & 45 & \mathrm{~S} .\end{array}$ $\begin{array}{lllllllllllllllllll}\text { Jupiter.... } & 18 & 7 & \ldots & 22 & 29 & \ldots & 2 & 51^{*} & \ldots & 15 & 48.4 & \ldots & 19 & 3 & \mathrm{~S} .\end{array}$

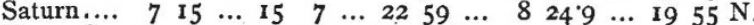
$\begin{array}{llllllllllllllllll}\text { Uranus'... } & 13 & 51 & \ldots & 19 & 31 & \ldots & \text { I } & 11 & *\end{array}$ $\begin{array}{llllllllllllllllll}\text { Neptune.. } & 2 & 53 & \ldots & 10 & 38 & \ldots & 18 & 23 & \ldots & 3 & 54.9 & \ldots & 18 & 41 & \mathrm{~N}\end{array}$ * Indicates that the setting is that of the following morning.

$\begin{array}{cccc}\text { June. } & \text { h. } & & \text { Mercury in conjunction with and } 2^{\circ} 29^{\prime} \text { north }\end{array}$ of the Moon.

$\begin{array}{llllll} & 2 & \ldots & 2 & \ldots & \text { Mercury at greatest elongation from the }\end{array}$ Sun $24^{\circ}$ east.

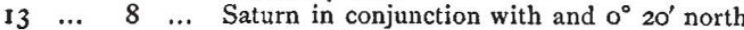
of the Moon.

Star. Variable Stars.

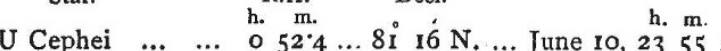

\begin{tabular}{|c|c|c|c|c|c|c|}
\hline S Cassiopeiæ & $\cdots$ & 114 & I $\mathrm{N}$. & ", & I6, & \\
\hline rum & $\ldots$ & $68 \mathrm{f} \ldots 22$ & $32 \mathrm{~N}$. & $"$, & 15, & \\
\hline minorum & $\ldots$ & $\begin{array}{lllll}7 & 16.9 & \ldots & 13\end{array}$ & $18 \mathrm{~N}$. & ", & II, & \\
\hline U Monocerotis & $\cdots$ & $5 \ldots 93$ & $33 \mathrm{~S} . \ldots$ & ," & 16, & \\
\hline minorum & $\cdots$ & 23 & 43 N. ... & $"$ & I4, & \\
\hline Libræ & $\ldots I$ & $1455^{\circ} \ldots .8$ & $4 \mathrm{~S}$. & $"$ & r5, & 254 \\
\hline achi... & $\ldots 1$ & $17 \quad 10^{\circ} 9 \ldots \quad 12$ & $20 \mathrm{~N}$. & $"$ & I3, & 34 \\
\hline rii & $\ldots \mathrm{I}$ & $17579 \ldots 293$ & $35 \mathrm{~S}$. & ," & 12 , & \\
\hline ræ... $\quad \ldots$ & $\ldots \mathrm{I}$ & 33 & 14 & $"$ & $16, \quad$ I & 10 \\
\hline$\cdots$ & $\ldots \mathrm{I}$ & $1946.8 \ldots 0$ & 43 & ," & 12,21 & \\
\hline & $\ldots 1$ & & &, & & \\
\hline & $\ldots 2$ & & & ", & & \\
\hline æ & $\cdots 2$ & $2046 \cdot 7$ & 50 & ", & 10,22 & \\
\hline & $M \operatorname{sig}$ & $\begin{array}{l}20594 \ldots 23 \\
\text { ignifies maximum }\end{array}$ & 23 & m. & 16, & \\
\hline
\end{tabular}

Meteor-Shozuers.

R.A. Decl.

Near $\alpha$ Vulpeculæ $\quad \ldots 286^{\circ} \ldots 24$ N. ... Rather slow. $\begin{array}{lllllllll}, & \alpha \text { Cephei } & \ldots & \ldots & 316 & \ldots & 60 & \text { N. .. Swift, streaks. }\end{array}$

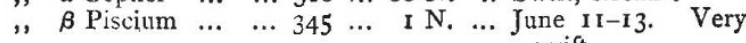
swift.

\section{GEOGRAPHICAL NOTES.}

MAJOR IIOBDAY reports of the operations in Upper Burma that during the season of $1887-88$, the whole of the Yaw country has been thoroughly surveyed by surveyors attached to the various columns converging on Gangaw. On the north a connection has been made with the work executed by Colonel Woodthorpe's party last year in the Kubo Valley. A good deal of the geography of the Schwele River and the Mohlaing district has also been ubtained. The extent of surveying that has been done by the surveyors who accompanied the column from Bhamo to Mogdung and thence by the Jade Mines and Endawgyi Lake to Katha, on the Irrawaddy, is not yet known, as reports have not yet been received. In the Southern Shan States a party under Lieut. Jackson, R.E., has carried on survey operations in continuation of last year's work from Fort Stedman to Pekon, in the Saga Valley, thence viá Maukme, and Moné to Maing-pan and the Salween River, where the Siamese mission under Mr. Archer was met. Returning to Moné, they carried the survey through Legya and Bansan to Maing-ye. In the Northern Shan States a sub-surveyor has carried our surveys from Thibaw to Namsan, and across the Myit.nge or Namtu River to Theinni, on the Salween, and thence vi $\dot{a}$ Maing-yaw to Manse and Maing-ye, thus effecting a junction with Lieut. Jackson's work. Major Hobday himself has extended the triangulation from Kyan Nyat to Bhamo, of which the position is thus determined, and a basis provided for the surveys in the direction of Mogaung. It is hoped that the triangulation executed by this party will be connected during this season with that of the surveys in Lower Burma. In addition to the work done by members of this department, many reconnaissances have been executed by regimental and other military officers and the results given to Major Hobday for incorporation in his sheets.

We are glad to notice that Signor Guido Cora's Cosmos now appears more regularly and frequently than formerly. The last number contains a detailed account of recent Danish expeditions in Greenland.

THE whole of the new number of the Deutsche Geographische Blätter is occupied with the narrative of J. G. Kohl's American studies, the results of journeys made thirty years ago in North America.

THE principal paper in the new part of the Zeitschrift of the Berlin Geographical Society is an elaborate examination of Sir John Mandeville's writings by Dr. A. Bovenschen, in which the author comes to conclusions decidedly unfavourable to Sir John's trustworthiness. Dr. G. Hellmann contributes an important paper on the rainfall of the Iberian peninsula. In the Verhandlungen of the same Society we find papers on the geography and ethnography of Southern Mesopotamia, by Dr. B. Moritz, and on the Isthmus of Corinth, by Dr. A. Philippson.

IT may be useful to state that in No. 1 of the third series of the Bulletin of the Egyptian Geographical Society is a connected account in French, by Dr. O. Lenz, of his last journey across Africa.

The June number of the Journal of the Royal Geographical Society contains the first part of Mr. D. W. Freshfield's paper on the Cancasus; it deals with Suanetia, and is illustrated with maps and diagrams. The same number contains Mr. Woodford's paper on his explorations in the Solomon Islands.

Two Swedish colonists, MM. Valdau and Knutson, have recently done some interesting geographical work in the Cameroons territory. M. Valdau has explored the northern slopes of the range, which are very thickly peopled by the Bomboko tribe. The main chain of the mountains does not extend as far as $4^{\circ} 30^{\prime} \mathrm{N}$. lat., as the highest point attained by the traveller, about $4^{\circ} 28^{\prime} \mathrm{N}$. lat., only measured 2850 feet. $M$. Knutson has explored the River Memeh, which, he ascertained, empties itself into the sea a little to the south of Rumbi. The river is navigable for thirty miles, to the Duben falls, which are roo feet in height. 